\title{
A Dead Sense of Time: Reflections on Architecture, History and Perception.
}

\section{Steve Basson}

\section{Abstract}

Our current conception of architectural history's normative possibilities return to the emergent surfaces of the eighteenth and nineteenth centuries where they crystallized around a conceptual framework expressive of a logical, progressive and trans-historical vision of time. But there is nothing inevitable about this perspective, or absolute. When Bergson spoke of the absurdity of teleology, Nietzsche of the congenital defects of the aeterna veritas, or Benjamin of the storm and violence of progress, the certainties of that legacy were compromised. In particular, the impact of such dissention upon the conventional space of architectural history would expose a realm of pure ends, a past that always presupposed its present and a future conceived through a blind lens of infinite perfection. What could also be said to reside in the wake of that same rational, continuous and periodized journey across the surfaces of architectures past, is a broad trail of destruction left by denying any autonomy of voice or contextual conditions of prior architectural identity. And yet, despite such questions of legitimacy, the gaze of architectural history remains focused upon a traditional view of time. Here there is no appetite for contestation or release, merely indifference, incomprehension or derision. But why such devotion to a marginalized conception of the past? Does such intransigence reflect a failure to recognize or fully articulate the limits of our traditional engagement with history; an innate desire for the security of familiarity and certitude; or perhaps from fear of an alternative and its potential dynamic of fragmentary, random and terminal moments of past architectural possibility. These issues that surround the historical authority and perception of architectures historical subject are pursued through the following considerations.

\section{Prologue}

Built upon a smooth levelled plain surrounded by a ragged and brooding wall of mountains, a vast architectural metropolis emerged from the dark shroud of night. Rigidly ordered, the city that came into view with the light of dawn spread out from a centre of modernist forms, moving chronologically 
towards those of the ancient world on its outer edges. At the heart of this urban mass was a square around which the creators of this realm returned with the day-break to tasks that had ever been focused on maintaining a rational sense and experience of this architectural landscape spanning from the temporally near to far. Here, through time honoured practices of observation, interpretation, writing and drawing, they upheld the lucid and tangible qualities of their architectural terrain born out of time and mind as a spatial reality open and accessible to all.

Later in the day, a man came running into the square crying out "History is dead! And we have killed it!” Whilst pausing for breath, all went silent around him. Looking up, he called out "Why labour as you do, have you not heard? History is dead! And we have killed it! The historical realm of architecture that we have for so long constructed and refined from unique insular origins, aesthetic forces of production, high points of heroic perfection and lows of tragic decline, and from a continuous line of various and successive periodized stages of development is no more than a parody. Our efforts have all been in vain, for this historical space that pronounces on the legacies and heritage of architecture is not the past, but a pale imitation of it. The past, however, is not so easily fooled or tamed by such reflections. Like the fabled realm of the Minotaur, it is filled with false and misleading passageways, dead ends and traps that lie ever in wait to seduce and overthrow the unwary viewer of time. Against this, the thread of historical reason that has guided us through the dark labyrinths of time lies cut in shreds as the outcomes of our historical dreams recompose into a nightmare of historicized distortions and obscurations born from a sense of trans-historical norms, reductive modes of inclusion and exclusion, and a perceptual regime that denies, effaces and in the end, terminates the very things we thought ourselves dedicated to giving voice, exemplifying and preserving. History is dead! And we have killed it!”

Having finished, the man stared about him seeing faces of bewilderment and shock turn to anger and hate. Surprised and then saddened by this reception, and amidst a now rising tide of hostility and denial, he spoke out once more "No! You have not heard! It is still too early! You are not yet ready!" With that he departed as he had come. As twilight fell across the purity of the city, the work of the day gradually wound down in preparation for the next. In the distance a runner could be seen heading back up into the mountains and the shadows of night and chaos. 


\section{Introduction}

The runner has departed, but not the raw and unyielding force of his dark pronouncement 'History is dead! And we have killed it!' We are left with the incitement of a statement enthused with all the subversive desires and revolutionary fervour of post-enlightenment thought. Here, too, we are confronted by the intimation of a crime and a question of demise that surrounds the corpus delicti of architecture’s historical terrain.

Such questions, however, are not new as posed by another and earlier messenger in whose footsteps our runner follows. This was Nietzsche's Wanderer who declared 'God is dead! And we have killed him! ${ }^{\mathrm{i}}$ For Nietzsche, the focus of this attack upon the bastions of late nineteenth century tradition and complacency was directed not at the dissolution of any actual metaphysical being or of any other illusion of ancient or superstitious invention. Pronounced here was a formal termination of that older idea of humanity that founded its physical form, values and truth on the conceptual image of a god, that figure born of our own inadequacies and whose perpetuation represented for Nietzsche the continued suicide of reason and the renunciation of human self-knowledge and will to power. ${ }^{\text {ii }}$ This was a wakeup call by which the Wanderer sought to provoke the realization and legitimacy of a human, all toohuman concept of humanity.

The assertion of death heralded by our allegorical runner also seeks to shatter the serenity of the familiar and expected. But in doing so, this does not summon into being an end to history or indeed of the past itself. The kind of death emphasized here concerns those temporally dispersed orders and contextually distinct relationships of past architectural purpose and identity perceptually suppressed and eradicated via the filtered view of a particular ideology and gaze of history. The modus operandi of this offence, for the runner, is to be found through those conditions of historical convention, historicism and heritage that preserve both a distorted sense of engagement with architecture's past terrain of built forms and a perspective attenuated towards the illusory vista of a continuous and rational space of time. Through this pronouncement of death, the runner calls for an acknowledgement of a crime, a victim and an idea of history that should be critically laid to rest and in exchange for this, investment within an alternative conceptualization of architectures past. In the face of this judgement and lingering dead 
hand of historical custom and habit, the stark words of the runner invite us to embrace the volatility of contestation and rupture.

What is asked for here is abandonment of the traditional terrain of architecture's historical subject and a stand against the misconceived ideals of an inherently knowable and trans-historical past. For within the inherited sanctity of this domain there is neither neutrality nor innocence. Here there is deception, control and death. And then there is the past, ever in view but never present. Such are the desires and claims of the Runner. But are these not also ours? Have we not recognized the limitations and failure of an historical perspective that has for too long advanced the experiences and norms of the viewer over those of the subject? Do we not wish to escape the corruption of meta-narratives, determinism and an ideologically governed sense of time? Or is it that we have not yet heard? And are we still not in fact ready to confront the implications and potential of various theories and critiques opposed to the dominance of historical conservatism?

But whether ready or not, the tide has ineluctably turned against history as a celebration of immutable truths and meta-historical deployments. And it is via a counter discourse that stretches back to at least Nietzsche, that it has been possible to repudiate progressive and essentialist visions of the past. Drawing from these varied sources of the historical other, what follows are some contemplations on why the conventional certitudes of architectural history, its surfaces of eighteenth and nineteenth century emergence, and modes of transgression represent an impoverished reality. In particular, by touching on those established objects of faith that promote the immediacies of seeing and knowing, privileged orders of visibility and the ever objective gaze of history, this is concerned with what may be implied from readings of architecture's past, no longer obsessed with what we see, as rather and more decisively, with how we see. What is considered here are a series of reflections on historical legitimacy, perception and how to re-think the problematical space and subject of architectural history. This is not, however, aimed at strategies for restoring the historical terrain of architecture to any realm free of doubt or anomaly or to revitalize its hidden unities, ancient continuities and authority. The focus of this discussion is framed around how we comprehend and visualize that space we call the past and from this, approach a more rigorous will to historical knowledge and, perhaps, finally come to terms with the fact that history is dead and we have killed it. 
Pevsner once wrote an 'age without architecture is impossible whilst human beings inhabit the world, iii What he meant by this pronouncement upon the ageless properties of architecture was not so much what was impossible as rather unthinkable, given an historical reality that portrayed the unique conditions of its subject as a continuous idea permeating the minds, practices and spatial forms of every era; as an unbroken language of thoughts, actions and material signs wholly recognizable and recoverable to the gaze of later historical observers; and as a linear course of events that marked out a progressive journey through time. But what is it that is so unimaginable? Is it to conceive an age possessed of buildings but not architecture and whose absence, once observed, would upset the grand sweep of architectural time? Might it be to renounce the trans-historical phenomenon of architecture that still clouds the way we view and employ its historical identity, surfaces of emergence and temporal relations? Then again, is it to discharge our allegiances to a history infuzed with its own self-sufficient and privileged order of ideas that flow paradoxically along a continual and unitary course of time, divided into autonomous and static segments of architectural expression? Or, is it perhaps to embrace the chimeras of what Tafuri referred to as the non-historical or anti-historical by denouncing the architectural traditions of the historically regular for an unnerving or nihilistic sense of the fragmentary and terminal ? $^{\text {iv }}$

Between what can be thought and expressed in words and what, as said by Wittgenstein, should be passed over in silence, these questions confront the conventional expectations of a contained and uniform vision of architectural history. ${ }^{\mathrm{v}}$ They equally touch upon the limits of those inherited prescriptions of historical imagination that appeared out of the rationalized conventions of the eighteenth and nineteenth centuries. The age of reason gave birth to a history of reason and the alluring dream of an explicable and purposeful domain of past ideas and actions. From the bounds of this perspective, the task of history was not to entertain doubt or uphold those older and reductive theological conceptions of divine origin and salvation. Time was instead a terrain to be conquered and history the instrument by which to tame its disparate parts and take possession on behalf of human heritage and destiny of what was true and eternal. The temporal reality that surfaced here was thus closed to conceptions that founded the principles of history upon what Kant disparagingly referred to as 
folly, childish vanity, malice and destructiveness. ${ }^{\mathrm{vi}}$ As a history dedicated to the recovery and commemoration of what guided and signified rational human thought and action, there were also no lessons here to be gained from those effects or practices that derived from humanity's so-called natural or base conditions of desire and instinct. For the high priests and children of the Enlightenment, as expressed by the all pervasive Hegel, ideas portraying the past as a realm of the inscrutable and incomprehensible or that sought to incorporate mere human striving and passion were to be treated with ruthless distain. ${ }^{\text {vii }}$

But the setting in advance of what is or is not of legitimate concern and value, to preclude and annul suggests no triumph over time as rather the sad victory of a narrowed and myopic gaze. This was, nevertheless, the outcome of a nineteenth century perspective obsessed with monitoring the boundaries of the rational and irrational and with upholding the specificities of giesteswissenschaften and naturwissenschaften. ${ }^{\text {viii }}$ The same, furthermore, can be said of the perceptual demands and reach of Western architectural history through the conceptualization and deployment of a subject that surrenders to the illusory perfection of an ordered and linear sequence of periods. What is described by the ages of ancient Egypt, Greece and Rome, those of the Medieval, Renaissance and Baroque, and of the eras of nineteenth century eclecticism, twentieth century modernism and, more recently, postmodernism, is a structured taxonomy of chronological phases. At the same time, there is nothing either essential or intrinsic to this historicized framework, only echoes from the distant classificatory overtures of Linnaeus and Winckelmann's periodized continuum of art and architecture. ${ }^{\text {ix }}$ On the other hand, it is a history that consigns differing degrees of merit and worth to each temporally zoned constituency of forms; that raises, for example, the architecture of Greece over Egypt, the Renaissance above the Gothic, and Modernism higher than nineteenth century revivalism, reinforcing the more ominous themes of exclusion and marginalization. It is also a history committed to abstracting and elevating the virtues of the architecturally great and the good, so exposing discriminatory and prejudicial methodologies of distinction. What we have yet to recognize is that the periodized domain of Western architectural heritage is a construct preserved through its own insular myths of architectural exemplification, origin and the arbitrary award of differing stylistic or spatial measures of rationality and aesthetics. 
The form and structure of history is not what it seems. Yes, it is possible to order time into a sequence of precise chronological regions that reflect individual intensities of the exceptional, unique or exclusive. Time is itself, however, indifferent to such vanities or dreams of idealized golden ages. But we should not be. We should instead stop following in the wake of a tradition inclusive of such as Viollet-Le-Duc, Fletcher and Gombrich, which compresses and isolates the architectural identity of particular periods from the wider and actual conditions of their own past and present; or conceiving of certain ages as autonomously and spontaneously entering the space of history as self-gestating moments of appearance ex nihilo. There is no contentment of legitimacy to be found here, merely, as observed by Foucault, a process aimed at immobilizing history in order to protect the manufactured identity of the emergent or principal subject of view. ${ }^{\mathrm{x}}$ History is not about any struggle for supremacy over the irrational or mediocre, for erecting barriers against the unimaginable and impermissible, or for conserving the heritage and perversity of counterfeit apotheoses. How we engage with an historical subject such as architecture will not be served by adopting the perceptual filtrations of historicist hierarchies and limits, or any play of predominances and withdrawals described by Nietzsche as the artificial isolation of stages especial to historical narratives concerned with producing a 'higher kind of picture' composed from an essentialized or reduced set of characteristics. ${ }^{x i}$ What is betrayed by such deficiencies for architecture's past, as with any history claiming a totality of definition and meaning abstracted from a selective range of possibilities, are the manipulative ends of inclusion and exclusion, the partisan features of surrendered objectivity, and an idea of historical space that represents no more than an arbitrary and self-fulfilling dream of hindsight. To reject such an organization of artificially inflated and diminished expressions of architectural periodization is also to counter the underlying mechanisms of an historical gaze that polices the primacy and coherency of a perspective that denies equivalence, visibility and even life from other moments of architectural being.

II

Those aggressive distinctions of historicized periodization comprise a deep-seated feature of our conventional experience of history. But then, so too do the presumptions of continuity and progression that sustain an infatuation for the temporally eternal and universal. It is compelling and seemingly obvious to conceive of architecture as a subject that spans from the 'dawn of history to the present' ${ }^{\text {xii }}$ It 
is from the same persuasive outlook of chronological duration, recurrence and linear advancement that we can continue to perceive ourselves heirs to the architectural fortunes of the past, the logical and natural inheritors of our predecessors' ideas, hopes and struggles. And yet to see time in this way represents, as through the inverted lens of a single point perspective, a convergence and channelling of events that approach the proximity of the viewer and vicinity of the present. Crucial to this conception of history is also the presence of a timeless subject of architecture flowing relentlessly along an unbroken line of development, of properties or essences that transcend the individuality of particular ages and movements. By calling upon what is progressive and continuous to the intentions or meanings of architecture and by holding firm to the idealized assertion of a past that forever informs and shapes the present is to reveal a proclivity for the meta-historical and attraction to a stable, common and directed subject of time. It is also to relinquish history to the will of metaphysical phenomena, of servitude to the intercessions of historicized imperatives and providence in Faustian exchange for a past unmarred by the vagaries of chance and incongruent immediacies.

Aristotle, however, was dismissive of history as reflecting anything other than a study of things that had been, declaring poetry to be of greater significance and philosophic merit given its concern for universals and the kinds of things that might be. ${ }^{\text {xiii }}$ The modern era's expectations of history, on the other hand, would run counter to these observations. Inspired by an integrated vision of history and capacity to make known the evolutionary conditions of humanity's road to infinite perfection, the Marquis De Condorcet would certainly have disagreed. ${ }^{\text {xiv }}$ In response to the presumed exigencies of world history and spirit, of the pure forces of mind and reason to propel the fulfilment of human fate and periodized articulations of self-realization, of zeitgeist, so too would Hegel. ${ }^{\mathrm{xv}}$ By being seen to afford measure and calculation of human destiny and expression of what guides the positive and transhistorical course of human affairs, historicized time transposes into a poetics of universals. It is, furthermore, when someone like Pevsner characterizes architecture as the product of an aesthetic spirit interlinking and informing the spatial and stylistic outcomes of each age or, more recently, Conway and Roenish who conceive the past as a legitimate instrument and model for building a better future, that the historical scope of architecture can be said to indulge in its own poetics of things that might be. ${ }^{\text {xvi }}$ But such indulgency is fundamental to any focus that historically asserts the permanency of the same intrinsic idea of architecture; to affirmations of a unifying constant that guarantees the sequential and undisturbed passage of architecture from the distance of the past to the present; or to insinuations of a 
predictive or benign programme of chronological evolution. To adhere to the possibilities of continuity and progress is to sponsor the enchantments of trans-historical discourse and the poetical allusions of universality and metaphysical agency.

Convention may well applaud the prospect of thousands of years of architectural heritage paraded as a continuous whole along a smooth progressive line of development. But what assures this apparition of historicized imagination belongs to what implicitly, although suppressed from conscious view, makes viable a chronological horizon of recurrent appearances and the supra-historical presence of a singular subject of architectural identity; to an undeclared commitment to what secretly binds and steers forms as historically disparate as pyramids, Palladian villas, gothic churches and inner city housing estates. The licensing of history as such a terrain of surreptitious causes and ends ultimately capitulates to a conception of time where, as noted by Bergson, 'beings and things simply realize a previously arranged programme'. ${ }^{\text {xvii }}$ By the same token, the ideas and products of architecture would be seen to act as no more than pawns to some hidden or indeed poetical hand of destiny. Plato distrusted poetry as a propagation of distorted realities. ${ }^{\text {xviii }}$ What then can be said of an historicist narrative given to the nobility of sovereign subjects, the temporal universality of ideas, and of architectures uninterrupted march across time towards the telos of its own future? Through his alto-ego Zarathustra, Nietzsche has already taught us to laugh at those figments of the historically linear and infinite and to treat with incredulity progression as a condition free of accident or instability. ${ }^{\text {xix }}$ The thoughts and actions of the past are not galvanized by the same interests, nor is the world of today a natural or positive successor to prior ages. And to the same extent that the past does not actively live in the present, nor do individuals live ahead of their own. The Hellenic Greeks did not forecast the architecture of Rome nor did the Neoclassicists of the mid-nineteenth century foresee Modernism. Here we should leave the mysteries of crystal balls and tarot cards to the practices of the arcane or to the spirit of Hegel and those 'worldhistorical individuals' capable of divining the next stage of the world to come. ${ }^{\mathrm{xx}}$

We can, of course, choose not to unsettle architecture's historicist dependence upon continuity and of any successive order of periods whose individuated moments of being exist as a direct outcome of those ages that preceded them and anticipation of those that would follow, lying beyond the ontological and epistemological margins of their own timeframe. We can, furthermore, refuse to expose traditional history as a terrain of guiding principles and essences retrospectively applied to the purposes of 
architecture or enter into any critique of a realm governed by the dogma of idealized ends and a present seen as a determined product of the past. But to do so endorses an idea of history that has for too long failed to disentangle the actualities of human thought, action and artifice from a desire for things that are always greater than mere mortal endeavour, from quasi-religious and supernatural engines of progression and future salvation. And then there is the cost that pursuance of the continuous and progressive imposes upon the historicity of events. This Benjamin portrayed through the figure of his 'angel of history' and the image of a past unveiled as a wasteland destroyed in the cause of progress by harnessing history into an expression of teleological forces, determining the path of human events and driving it blindly into a future of illusory promise and mythical perfection. ${ }^{x x i}$ Such carnage remains a condition of the social, cultural and political contexts particular to each temporal setting of architecture crushed beneath the accreted weight of grand recit obsessed with the ingrained features of the timeless and universal. It is not the meta-narratives of history that are dead, only their victims. And it is not so much the figure of any angel of history who can be said to preside over the destructive course of conventional time as rather, an angel of death.

\section{III}

To choose the tempest of the progressive and trans-historical is to refuse to recognize that the contextual and rationalized subtleties of prior eras exist largely beyond the reach of contemporary perception. But then the perspective of historicist thought is not predicated upon what is closed or alien to the comprehension of later observers. The possibilities of historical convention are instead grounded upon a past that is conceived ever open, lucid and, most of all, alive to the thoughts of the present? Custom would have it that any reading of history is founded not on what obscures or truncates the interpretative scope of the historian but upon the appropriation of subjects that appear through a common and exchangeable currency of concepts and meanings. This sense of reciprocation allowed the neo-Hegelian Collingwood to conceive history as the definitive analysis of human thought and the task of historians to re-think and judge those thoughts through a process that called upon their cogitative reenactment within the historian's own mind. ${ }^{\text {xii }}$ In this manner of self-reflection, the potential distance, impenetrability and limitations of time could be guaranteed to evaporate before an ideal of temporal participation that consigns the past and present to a shared space of thought and identity. 
But is it not this same method and sense of a mutually inclusive domain of correspondences and affiliations that sustains architecture's engagement with the built forms of its past; with the reconstitution of their aesthetic character, spatial organization and function; the recovery of their meanings and reinstatement of their vitality? Architecture's received conditions of historical possibility, which according to Conway and Roenish seek to understand and find explanations for the architectural past, ${ }^{\text {xxiii }}$ hinge upon the effortless merger between the viewer and subject of view and with what empowers language and reason to describe and render explicable. It is this implied sense of equivalency that fulfils the interpretative ambitions of historical imagination and by so doing, animate what is dormant and transform the ruins and preserved forms of architecture's past into objects of the known and familiar. From the perspective of historicist reciprocity and its parallel states of experience and comprehension, nothing can be lost to view and understanding or left to languish as romantic exemplars of remorse and melancholy. Moreover, it is by conceiving the icons of architecture's historical landscape as the products of common ideas and norms that sites such as the Acropolis or Chartres can be perceived as direct and unified constituents of our heritage, our reality, of ourselves.

Too much, however, is asked of a past that is perceived to replicate the dynamics of contemporary thought, to mirror its desires, or offer the certitude of return and participation. The world, said MerleauPonty, is not what we think, but what we live through. ${ }^{\text {xiv }}$ But whilst we can physically inhabit the urban and built forms of architectures heritage, visually interact with their surfaces and fill out their spaces with the bric-a-brac of time, we cannot see in the same way as their distant occupants nor live out and experience the rationalized conditions of their world. Each age, like the contained and insulated realm of Plato's cave, defines the reality of a particular and internalized order of knowledge, perception and experience. ${ }^{x v}$ Against this, as observed by Derrida, we have no language or form of logic other than our own to construct the meanings and values of earlier ages. ${ }^{\text {xxi }}$ By extension, the architectural forms of the past lie outside of what spatial experience is for us, or that inform the rationalized conditions of our architectural knowledge and purposes of production and meaning. To ask the past to speak to us in its own terms, as through the roar of Wittgenstein's lion, is to invite incomprehension via the distance that separates us from the world of experience that underpinned their language and circumstances of architectural possibility. To conceive earlier ages as both totally accessible and explicable to the gaze of history is also to ignore, again borrowing from Wittgenstein, that the past and 
present constitute two incompatible spaces in time, devoid of any shared sense of experience, definition or judgement. ${ }^{\text {xxvii }}$

The past is not an open book. We should recognize instead, as did Benjamin, that what invests our sense of the historical comprise relations that are consumed by the presences of the now and what is incapable of being accommodated within the perceptual terms of the present, disappears. ${ }^{\text {xxviii }}$ In these terms, those once incorruptible appropriations and products of historicist endeavour disclose a condensed organization of architectural ideas that do not signal the contextual actualities of the temporally distant, but the distilled subjects of an historical economy of thought reflective of the rational and epistemological expectations of the present. Given this, the imperative to speak uncritically on behalf of architecture's past can only be said to endure by failing to grasp that history, following Foucault, is devoid of all meaning or, at least, possessed of no meanings other than those imposed by ourselves. ${ }^{\text {xxix }}$ Nietzsche's response to those who naively employed a model of themselves, their own contemporary ideas, beliefs and value systems as the standard by which to read and interpret the past was to condemn them as congenitally defective. ${ }^{\mathrm{xxx}}$ On the other hand, it is by doubting what has to date comprised an unassailable tenet of historical belief and perception, that we should learn to acknowledge that history in its conventional form is a construct that can never be the past itself, only ever a representation manufactured from the perspective of the present.

History, like the 'baseless fabric' of Prospero's visions, conjures into view the illusionary reality of a past that is always absent: a presence never realized, only ever represented through an idea of history. As part of this same 'insubstantial pageant', the 'cloud-capped towers, gorgeous palaces and solemn temples' of architecture's past comprise narratives in stone, encrusted with the intrusive signatures of the present, meanings born of contemporary invention and congenitally defective investments of interpretation and rationality. ${ }^{\text {xxi }}$ What fades as a result of this is the perceptual integrity and omnipotence of the all knowing and unrestrained gaze of historical tradition and with it, the transhistorical dream of temporal participation and experience. Destitute of the ideals of accessibility and comprehension, the past can only return to what it had always been, a terrain of transitory and nontransferable relations of architectural possibility that are incapable of resurrection in their own terms. What is left to view for convention is a portrait of the past that is no more than a product of the colonizing thrust and narcissistic excesses of a present that has yet to engage with what informed each 
earlier age's will to build, of what made it possible for them to think, inhabit and spatially design in relation to their own perceptual constellations of reality.

\section{IV}

The reach of current historical imagination remains largely bound to the temporal constraints of the continuous, progressive and participatory. And yet there is nothing essential about these canons of historicist creed or their dispersal through the subjects of architectures past. Here there is merely habit: habits can be broken. But to contemplate overturning the traditional obsessions of history would require a radical, perhaps even heretical re-conceptualization of architecture's historical conditions of possibility. Such a rupture would represent, however, the potential to move away from any unitary or trans-historical sense of architecture's past towards a perceptual field of multiple realities that promise no haven of return or certitudes of truth and legibility, those old staples of historicist and heritage doctrine. Also approached by such possibilities is another will to historical knowledge, not the sacrifice of mind upon some historicist cross of eternal resurrection. On the other hand, by considering such a goal, this should not be seen as laying open the malevolent and chaotic forces of Pandora's box and through them, destroying the very substance of history and time but, as underscored by Foucault, their transformation into a form that repudiates any realm of 'metahistorical deployments, ideal significations and indefinite teleologies' xxxii What is asked for here ultimately is a change in historical beliefs and of what Danto called a 'revolution of historical reality'. xxxiii

To reject the beliefs and realities of tradition is inevitably to smash the pedestals upon which are set the venerated and sacred objects of architecture's past, it is to eliminate the myths of golden eras and render imaginable a sense of time undisturbed by any 'higher' or 'inferior' temporal segments of architectural appearance. Such graduations of periodized significance and linear demarcation do not of course speak for the past itself: they never did, only ever of prescriptions insisted on by a present infatuated with its own incarnations of privileged heritage and chronological hierarchy. Such is one of the most intractable features of historical conservatism, the conceited authority to judge and condemn

whole eras. Surrendering to this compulsion to elevate one age above another or to disingenuously apportion values and moral verdicts impoverishes the interests and subjects of architectural history. The 
past can only be what it was from the perspective of the past no matter the state or conviction of contemporary Western sensibilities. It is only those who come after that pronounce on the historical nature of lesser or highly developed ages of architecture and who allow themselves the luxury of being morally outraged by such as the games conducted within the Coliseum, or sacrifices associated with Aztec temples. The historical realm of architecture is not possessed of any eternal norms of form and function that some ages fulfil and others transgress. To realize the actualities and complexities of architecture's historical domain is to understand, as suggested by Geach, the prejudices of both the past and present. $^{\text {xxxiv }}$ It is also to avoid the discrepancies of totalization. The historical conditions of an era such as the Renaissance will not be critically served by consigning all architectural, cultural or political relations to the sweeping generalization of 'rebirth' as though this captures, as some scurrilous expression of zeitgeist, the entirety of intentions and purposes for everything conceived over the period. To speak of the historical other is, instead, to refer to a temporal space of suspended judgements, of a terrain that stands beyond the measures of good and evil and where the historical subjects of architecture are framed around what informed their own individuated conditions of social production and consequence.

In order to ground what is particular to any given moment of architectural appearance, of what discursively underpins each temporal threshold of spatial possibility, one must conceptually discard not only those naive assertions of periodized classification and value-laden judgements but also the sovereignty of any homogeneous, continuous or progressive subject of time. Architectural history is still predominantly read in the terms of a singular and cohesive story portraying its subject's uninterrupted and indeed heroic march across time. What this promotes is a fictional account of chronological passage and a misconceived alliance with the covert intervention of metaphysical drives and agents, historical imperatives and programmed ends. There are no rules, laws or forces of historical development. Their adoption merely placates what Feyerabend called our 'lower instincts'. ${ }^{\text {xxx }}$ To seek the rewards of meta-narratives and predetermination is thus to invoke an historical field of illusionary drives and subjugated constituents. Their abolition, on the other hand, requires no more than a conscious decision to step away from the ideology and treadmill of progress. Such a move, however, would represent no simple incorporation of what Vattimo saw as an architectural realm of multiple stories, histories and truths. ${ }^{\text {xxxvi }}$ On the far side of the continuous and meta-historical, the temporal subject of architecture would appear as a condition of competing paradigms, of splintered, and 
truncated linear spans of architectural manifestation; and of disparate and indeterminate relationships of architectural being. Here would also eventuate an historical space emancipated from the phenomena of architectural typologies, that eighteenth century bye-product of classificatory and regulating discourses. To encounter the historicity of architecture is to acknowledge, as exemplified in Foucault's Discipline and Punish on the issue of prison design, that built forms do not respond over time to any evolutionary plan. ${ }^{\text {xxvii }}$ They represent separated identities that express divergent needs and conceptions of spatial organization and function. The dark dungeons of the ancien regime did not lead to the exposed cells of inspection and behavioural control that would follow. As an outcome of this, one can no longer speak safely of natural progression or even of social advancement, only of breaks and dissolution. It is in the absence of convention and any progressive structure of time moreover, that the multiple subjects of architecture's past would critically reconfigure into components of discontinuous and fragmented states of historical transition.

For architecture, what commitment to an idea of the historical other primarily entails is recognition of temporally disrupted identities and through them the suppressive reality of imposing values and motives. In particular, what would be expected here is the mounting of offensive operations against the old mindset, discriminations, trans-historical vantage and participatory fantasies of historicisms high priests and acolytes. Teyssot approached this in the terms of treating as problematic any historical sense of cognitive transmission. ${ }^{\text {xxviii }}$ Kipnis more directly called upon doing battle with the very meaning of architecture. $^{\text {xxxix }}$ But whether identifying problems or the inherently repressive nature of traditionalist readings of time, the underlying key to any re-engagement with the historical landscapes of architecture will only be found by entering into another perceptual contract with the past. Signalling a permanent attack upon any state of the meta-historically lucid and stable, what such an agreement would represent is the subversion of historical perception, of an ongoing process of perceptual insurgency aimed at unsettling the authority of essentialist and absolutist thought by rendering the individuated points of architecture's past apparent in their own terms. The focus of such agitation, however, should not be seen as targeted so much upon the past itself as on how we perceptually infiltrate and interpret its many architectural possibilities, on how far we can defer those treacherous inclinations to explain architecture's earlier conditions of being from the contemporary perspective of our own epistemological and ontological realities. The buildings of prior ages, like words and text, remain a physical reality. But our interpretation of them will not be helped by continuing to explore what 
directly links one age to another or with how we can all think the same things. Here we must actively oppose the automatic assumptions and complacency of historicist rationalization, periodized succession and progress that still haunts the temporal gaze of architecture. And, by so doing, learn how to approach the past unencumbered by any taste for discovering what is legible or palatable for us, as with what, no matter how strange or exotic, informed their own architectural relationships of discursive and socio-cultural production. And yet, given the problematic nature of an inherited idea and structure of architectural history, it is not impossible to re-conceive our perceptual engagement with the past or expose what has traditionally been obscured and eradicated from view. It is certainly not unthinkable to consider a broader and more dispersed realm of history that draws on differing orders of architectural reality, division and transmission of ideas. In which case, what would also become imaginable for the historical scope of architecture would be investigations that resolutely sought to uncover what empowered and made it possible to think in a particular way about architecture from within the bounds of any given moment of time, with what in fact was contextually especial to each architectural subject's underlying conditions of what could be seen, said or known.

\section{Conclusion}

For too long the inconsistencies and vanities of an entire historical tradition committed to the promise of rationalized imperatives, eternal truths and of progressive visions of time have laid claim to the imagination of architecture. What is also long overdue are questions that would break the inhibitions of custom by asking unconditionally of whom history should speak on behalf of, in whose voice such enunciations should be proclaimed, and from whose perspective expression should be afforded each prior articulation of architectural possibility. By leaving such issues of engagement and interpretation unchallenged, the perceptual conflicts and compromises of convention are allowed to thrive and perpetuate a repressive hold upon the historical terrain of architecture whose resultant order of permitted appearances and identities can only ever transpose into a dark necropolis of funereal monuments, dedicated to a lost past of eradicated and lifeless forms. This was the message of the runner and focus of the critical reflections of this discussion. And yet, what was undertaken here did not seek to resolve the array of deceptions and inadequacies distinctive to the traditional authority and perceptual view of architectural history. Nor were these considerations centred on discovering some 
flawless path to historical knowledge. From the standpoint of historical perception, the past will always remain problematic. But this does not mean that we are doomed to forever follow the path of historicist invention. There is a choice. For the historical subject of architecture this would concern how to begin to re-think and approach the past as it is, not as we would like it to be and as a consequence, avoid the hostility and crimes of an historical environment that eliminates from view anything perceived unworthy of historical merit or that would destabilize the meta-historical and teleological purity of architecture's conventional conditions of temporal being. But until such a point of contest is reached, we must suffer the harsh reality that the actuality of the past represented by architectural history is dead and will remain so whilst we continue to act as its executioner. 
Notes

${ }^{\mathrm{i}}$ Friedrich Nietzsche, The Gay Science, Walter Kaufmann (trans), New York: Random House, 1974, p. 203.

${ }^{i i}$ Friedrich Nietzsche, Beyond Good and Evil, R J Hollingdale (trans), Harmondsworth: Penguin, 1990, p. 75.

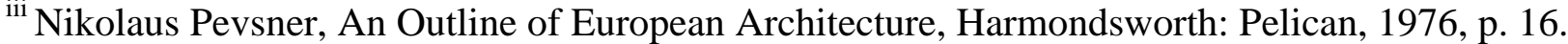

${ }^{\text {iv }}$ Manfredo Tafuri, Theories and Histories of Architecture, St Albans: Granada, 1980, p. 6.

${ }^{v}$ Ludwig Wittgenstein, Tractatus logico-Philosophicus, D F Pears \& B F McGuinness (trans), London: Routledge \& Kegan Paul, 1971, p. 151.

${ }^{v i}$ Immanuel Kant, On History, Indianapolis: Bobbs-Merrill, 1975, pp. 12-13.

vii G W F Hegel, Philosophy of Right, T M Knox (trans), Oxford: Oxford UP, 1967, p. 216.

viii Arthur Danto, Narration and Knowledge, New York: Columbia University Press, 1985, p. 205.

ix J J Winckelmann, “History of Ancient Art, 1764,” in Eric Fernie (ed) Art History and its Methods: a critical anthology, London: Phaidon press, 1995, pp. 70-76.

${ }^{x}$ Michel Foucault, "Nietzsche, Geneology, History,” in Paul Rabinow (ed), The Foucault Reader: An introduction to Foucault's Thought, Harmondsworth: Penguin, 1991, p. 78

${ }^{x i}$ Friedrich Nietzsche, Human, All Too Human, Marian Faber \& Stephen Lehmann (trans), London:

Penguin Books, 1994, pp. 166-167.

xii R Furneaux Jordan, A concise History of Western Architecture, Norwich: Thames and Hudson, 1979, p. 6.

xiii Aristotle, Poetics, John Warrington (trans), London: Dent, 1963, 1460a.

${ }^{\text {xiv }}$ Michael Baker, Condercet: Selected Writings, Michael Baker (ed), Indianapolis: Bobbs-Merrill, 1976

${ }^{\mathrm{xv}}$ G W F Hegel, Philosophy of Right.

${ }^{x v i}$ H Conway \& R Roenisch, Understanding Architecture: An Introduction to Architecture and Architectural History, London: Routledge, 1997, p. 30; Nikolaus Pevsner, An Outline of European Architecture, p. 17.

xvii Henri Bergson, Creative Evolution, New York: H Holt \& Co, 1911, p. 39.

xviii Plato, The Republic, Desmond Lee (trans), Harmondsworth: Penguin, 1987, pp. 421-431.

${ }^{x i x}$ Friedrich Nietzsche, Thus Spake Zarathustra, Thomas Common (trans), Hertfordshire: Wordsworth Editions, 1997, p. 154-156.

${ }^{\mathrm{xx}}$ G W F Hegel, Lectures on the Philosophy of World History: Introduction, Reason in History, Cambridge: Cambridge University press, 1975, p. 39.

${ }^{x x i}$ Walter Benjamin, Illuminations, Harry Zohn (trans), New York: Schocken Books, 1973, pp. 257258.

xxii R G Collingwood, The Idea of History, Oxford: Clarendon Press, 1946, p. 215.

${ }^{x i i i i}$ H Conway \& R Roenisch, Understanding Architecture: An Introduction to Architecture and Architectural History, p. 29.

xxiv Maurice Merleau-Ponty, Phenomenology of Perception, London: Routledge \& K Paul, 1962, p. xvi ${ }^{x x v}$ Plato, The Republic, pp. 316-325.

xxvi Jacques Derrida, Writing and Difference, Alan Bass (trans), London: Routledge \& Kegan Paul, 1978, p.280.

xxvii Ludwig Wittgenstein, Philosophical Investigations, G Anscombe (trans), Oxford: Basil Blackwell, 1968, p. 88e.

xxviii Benjamin, Illuminations, p. 259, 255. 
${ }^{\text {xxix }}$ Michel Foucault, Michel Foucault, Power/Knowledge: Selected Interviews and other Writings 1972-1977, C. Gordon (ed), London: Harvester, 1980, p. 114.

${ }^{\mathrm{xxx}}$ Friedrich Nietzsche, Human, All Too Human, p. 14.

${ }^{x x x i}$ William Shakespeare, 'The Tempest', Shakespeare Vol 1: The Comedies, London: J M Dent \& Sons, 1995, p. 47.

xxxii Michel Foucault, “Nietzsche, Geneology, History,” p. 77.

xxxiii Arthur Danto, Narration and Knowledge, p. 327.

xxxiv Peter Geach, Mental Acts: Their Content and Their Objects, Routledge \& Kegan Paul, 1971, p. 116.

${ }^{x x x}$ Paul Feyerabend, Against Method, London: Verso, 1988, p. 27.

${ }^{x x x v i}$ G Vattimo, “The End of Modernity, The End of the project?,” in Neil Leach (ed), Rethinking Architecture, London: Routledge, 1997, p. 149.

xxxvii Michel Foucault, Discipline and Punish: The Birth of the Prison, Harmondsworth: Penguin, 1991. xxxviii Teyssot, "Heterotopias and the History of Spaces," Architecture and Urbanism, vol 121, 1980, p.

80.

xxxix J Kipnis, “Twisting the Separatrix,” in K M Hays (ed), Architecture Theory Since 1968, Cambridge, Massachusetts: MIT Press, 2000, p. 710. 